\author{
А. Біла-Кисельова, \\ кандидат юридичних наук, \\ суддя Білозерського районного суду Херсонської області, \\ сертифікований тренер Національної школи суддів України
}

\title{
ПОГЛЯД ЄВРОПЕЙСЬКОГО СУДУ 3 ПРАВ ЛЮДИНИ НА РОЛЬ «РUВLICWATCНDОG» ДЛЯ ІНТЕГРАЦІї ПРАВОСУДДЯ В СУСПІЛЬСТВО
}

Р. Рейган наголошував, що інтелектуальна свобода означає визнання того, що жодна людина, заклад, уряд не має монополії на правду, що життя індивіду має безкінечну цінність і має сенс, а тому кожен у ньому володіє правом дати щось світові [1].

Саме тому у світі з'явилася й реально працює опція «publicwatchdog» («сторожовий пес демократії).

В Україні кожному гарантується право на свободу думки і слова, на вільне вираження своїх поглядів і переконань (стаття 34 Конституції України). Кожен має право вільно збирати, зберігати, використовувати й поширювати інформацію усно, письмово або в інший спосіб - на свій вибір [2].

Сьогодні суд як ключовий елемент у забезпеченні дотримання прав і свобод людини перебуває під пильним оком громадян, а судді як частина судової системи перебувають під постійним контролем у суспільства.

Громадські організації, 3MI, громадяни й адвокати вивчають роботу судів (суддів), аналізують сучасний стан правосуддя, повідомляють про рівень «доступу до правосуддя» та загальну практику в судах за окремими категоріями справ, а також про рівень кваліфікації судового персоналу. У зв'язку 3 цим направляють запити до судових органів; збирають та обробляють отриману інформацію; поширюють опрацьований матеріал на сторінках газет і в мережі Інтернет.
Завдяки безперервній роботі суспільства і правосуддя вдосконалюються державні інститути.

Саме тому система правосуддя повинна поважати роль суспільних запитів, роботу ЗMI й недержавних інституцій, які працюють 3 метою виявлення недоліків та участі в удосконаленні судових процедур, якості послуг, які суди пропонують.

Така сучасна робота суспільства і правосуддя триває в усіх країнах, що підтримують ідею демократії та верховенства права.

Це підтверджується у Висновку № 7 (2005) Консультативної ради європейських суддів до уваги Комітету Міністрів Ради Європи «Правосуддя та суспільство» (далі - Висновок): «Правосуддя $є$ важливим компонентом демократичних суспільств. Воно має на меті вирішення спорів між сторонами i, шляхом прийняття рішень, виконання як «нормативної», так і «просвітницької» ролі, надаючи громадянам відповідні настанови, інформацію та запевнення щодо права і його практичного застосування» [3].

Публічність розгляду справ у тому сенсі, як це закріплено в статті 6 Європейської конвенції з прав людини, традиційно розглядається як єдиний контакт між судами та громадськістю, що зробило 3 MI й недержавні громадські організації для судів основами зв'язку із зовнішнім світом, громадянами, особами, які звернулися за захистом своїх прав. 
Європейський суд 3 прав людини (далі - ЄСПЛ) звертає увагу на питання захисту інституту демократії та прав людини: «... будь-яке тлумачення прав і свобод, які гарантуються, має відповідати «загальному духу» ...»; «Хоча іноді й потрібно підпорядковувати інтереси особи інтересам групи, демократія не зводиться до постійної переваги думки більшості, вона передбачає рівність, яка забезпечить справедливе ставлення до меншин і виключає будь-яке зловживання становищем» [4, с. 36-38].

Також ЄСПЛ виокремлює опцію «publicwatchdog» («сторожовий пес демократії), яка $€$ доцільною та має бути чинна в демократичному суспільстві для інтегрування правосуддя в суспільство.

Питанню дослідження практики ЄСПЛ щодо ролі судової влади у зв' язку «суспільство - правосуддя» займаються науковці та судді: Т.О. Анцупова, В.Н. Денисов, О.Р. Кібенко, П.М. Рабінович, В.В. Мицик та інші. Разом із тим дослідження опції «publicwatchdog» та іï оцінювання в роботі судової влади в розрізі рішень ЄСПЛ потребує додаткового вивчення. Тому тема актуальна сьогодні.

Метою статті є визначення сутності опції «publicwatchdog» у розрізі рішень ЄСПЛ під час роботи правосуддя для інтеграції в суспільство.

Рада Європи за результатами П'ятої зустрічі голів європейських верховних судів на тему «Верховний Суд: публічність, видимість і прозорість» (м. Любляна, 6-8 жовтня 1999 р.), Конференції голів асоціацій суддів на тему «Правосуддя та суспільство» (м. Вільнюс, 13-14 грудня 1999 р.) i Європейської конференції на рівні міністрів 3 питання політики щодо засобів масової інформації (м. Київ, 10-11 березня 2005 р.) затвердила Висновок № 7 (2005) Консультативної ради європейських суддів Комітету Міністрів Ради Європи «Правосуддя та суспільство», відповідно до якого надала такі рекомендації судам: «Таким чином, необхідно виконувати свій обов’язок, керуючись рішеннями Європейського суду 3 прав людини, з тим, щоб знайти баланс між конфліктуючими цінностями захисту людської гідності, приватності, репутації та презумпції невинуватості, 3 одного боку, та свободи слова, 3 другого (п. 52)» [3]. А також звернула увагу на те, що 3MI відіграють вирішальну роль у забезпеченні права громадськості на інформацію та доступ до документів, за словами ЄСПЛ, як «сторожовий пес демократії».

У Висновку зазначається: «Розвиток демократії в європейських державах означає, що громадяни повинні отримувати належну інформацію про організацію органів публічної влади та умов, в яких створюються закони. Крім того, для громадян так само важливо знати про те, як функціонують установи судової системи» [3].

Думка Ради Європи узгоджується з частиною 2 статті 19 Міжнародного пакту про громадянські й політичні права: «Кожна людина має право на вільне вираження свого погляду; це право включає свободу шукати, одержувати і поширювати будь-яку інформацію та ідеї ...» [5].

Крім того, у статті 11 Конвенції про захист прав людини і основоположних свобод указано: «Кожен має право на свободу вираження поглядів. Це право включає свободу дотримуватися своїх поглядів, одержувати i передавати інформацію та ідеї без втручання органів державної влади і незалежно від кордонів» [6].

ЄСПЛ у справі Sunday Times v. The United Kingdom визначив: «Суд не може діяти у вакуумі. Хоча вони $€$ форумом для вирішення суперечок, це не означає, що не може бути попереднього обговорення спорів в інших місцях, чи то у спеціалізованих журналах, у широкій пресі, чи то широкою громадськістю. Крім того, хоча засоби масової інформаціі не мають перевищувати межі, накладені в інтересах належного здійснення правосуддя, на них покладено обов'язок передавати 
інформацію та ідеї щодо питань, що надходять до судів, як і в інших сферах, що становлять суспільний інтерес» (п. 65) [7].

При цьому Висновок КРЄС № 1 Про стандарти незалежності судових органів і незмінюваність суддів роз'яснює роль правосуддя в суспільстві й підтверджує тезу: «Незалежність судової влади запорука справедливого правосуддя»: «На суддів «покладається обов'язок приймати остаточне рішення 3 питань життя та смерті, свободи, прав, обов'язків і власності громадян» (як це передбачено у вступі до Основних принципів ООН, що відображені в Пекінській декларації, а також у статтях 5 і 6 Європейської конвенції 3 прав людини). Незалежність судів $є$ прерогативою чи привілеєм, що надається не на користь власних інтересів суддів, а на користь забезпечення верховенства закону та в інтересах тих осіб, що покладають надію на правосуддя» [8].

В умовах сучасної роботи судової влади суспільний інтерес спрямований не тільки на розгляд конкретних справ, аналіз стану правосуддя й загальну практику розгляду справ у судах за окремими категоріями, а й на рівень кваліфікації судового персоналу, родинних зв’язків, майнових права, що виникли в процесі перебування суддів на посадах тощо. Про це свідчать офіційні сторінки сайтів судової влади й інформація про щорічну звітність. Кількість запитів збільшується від громадських організацій, окремих громадян, 3MI.

Варто звернути увагу на те, як ЄСПЛ наголошує, що опцією «publicwatchdog» можуть бути наділені не лише 3MI безпосередньо, а й громадські організації, які звертають увагу на питання, що становлять публічний інтерес (Magyar Helsinki Bizottsag v. Hungary) (п. 166) [9].

У справі Thoma v. Luxemburg ЄСПЛ зазначив: "Civilservants», здійснюючи свої повноваження, як і політики, є суб'єктом ширших лімітів допустимої критики, ніж приватні особи» (п. 47) [10].
Крім того, ЄСПЛ у справі De Haesand Gijsels v. Belgium підкреслює: «Суди - гаранти справедливості, роль яких $€$ основоположною у державі, де визнається й діє принцип верховенства права, - повинні користуватися довірою громадськості. Відповідно, вони повинні бути захищені від руйнівних нападів, які $€$ безпідставними, особливо зважаючи на той факт, що судді підлягають обов'язку дискреції, що не дозволяє їм відповідати на критику» (п. 37) [11].

Тож можна говорити, що судді та судовий персонал $€$ суб'єктами, про які йде мова в рішенні по справі Thoma v. Luxemburg, опцією «publicwatchdog» можуть користуватися всі зацікавлені особи, якщо метою $€$ інтегрування правосуддя в суспільство, викорінення корупції в судовій владі, формування висококваліфікованого суддівського корпусу та цього вимагає суспільний інтерес.

Разом із тим обмеження, які можуть стосуватися «publicwatchdog» під час висвітлення інформаціі, можуть стосуватися й авторитету правосуддя та дотримання стандартів щодо незалежності судової влади. Це підтверджено у Звіті Спеціального доповідача щодо незалежності суддів і юристів Комітету з прав людини ООН від 29 квітня 2019 року: «Обмеження свободи вираження можуть бути припустимі, якщо це необхідно для захисту авторитету судді» (п. 52) [12].

У справі CENTRE FORDEMOCRACY AND THE RULE OF LAW v. Ukraine ЄСПЛ звернув увагу на таке: «Інформація, дані чи документи, до яких запитується доступ, мають, як правило, відповідати критерію суспільного інтересу для того, щоб викликати необхідність ї розкриття згідно з Конвенцією. Така необхідність може існувати там, де, окрім іншого, розкриття інформації забезпечує прозорість ведення державних справ або питань, які становлять інтерес для суспільства в цілому, і завдяки чому дозволяється участь суспільства 
в цілому у державних справах (там само, § 161) (пункт 84 Рішення). Суд підкреслював, що визначення того, що може бути предметом суспільного інтересу, буде залежати від обставин кожної справи. Суспільний інтерес належить до питань, які впливають на суспільство настільки, що воно може законним чином цікавитись ними, які привертають його увагу або які стосуються його в значній мірі, особливо коли вони мають вплив на добробут громадян або життя суспільства/громади. Це також стосується питань, які можуть призвести до значних суперечок, стосуються важливих соціальних питань або проблеми, до якої суспільство має інтерес чи про яку має бути поінформованим. Суспільний інтерес не може бути зменшено до жаги суспільства на інформацію про приватне життя інших осіб чи бажання аудиторії до сенсацій чи навіть вуайєризму. Для з'ясування того, чи належить документ до предмета загальної важливості, необхідно оцінити документ в цілому з урахуванням наявного в ньому змісту (там само, § 162) (пункт 85 Рішення)» [13].

Крім того, ЄСПЛ неодноразово наголошував, що запитувана інформація відповідає «тесту на суспільний інтерес», якщо вона стосується осіб, які $€$ політиками, державними службовцями, суддями та надають «державні послуги».

Рада Європи неодноразово у звітах підтвердила також тезу, що суспільство має право отримувати інформацію, що стосується судової влади, і налагоджувати співпрацю зі 3MI, а також не забороняється висвітлювати інформацію, яка б стосувалася доброчесності всіх, хто представляє владу та працює на благо прав людини. Саме тому Вища кваліфікаційна комісія суддів України у 2015 року відкрила відомості про суддів щодо родинних зв'язків, кваліфікації та освіти тощо.

У справі CENTRE FOR DEMOCRACY AND THE RULE OF LAW v. Ukraine ЄСПЛ підкреслив роль «publicwatchdog» і звернув увагу на публічну сферу: «... роль організації-заявника як недержавної організації, що здійснює важливу функцію «сторожового пса демократії, не оскаржується ... Суд підкреслює, що хоча така інформація є особистими даними, які пов'язані з освітою та професійною діяльністю політичних лідерів, останні у своїй більшості належать до публічної сфери» [13].

Необхідно підсумувати, що, незважаючи на незалежність судової влади, вона має гарантуватися національними стандартами на максимально можливому високому рівні, інтегрування правосуддя в суспільство можливо завдяки «publicwatchdog». Опція «publicwatchdog» $є$ чинною в демократичному суспільстві для вдосконалення державних інститутів, ЄСПЛ підтверджує про це в практиці. Суддя є фігурою сучасного суспільства, а отже, суспільний інтерес до такої фігури $€$ виправданим для утвердження довіри до всієї судової влади й формування демократичної України.

У статmі проаналізовано рішення ЕСПЛ у розрізі діяльності осіб, що перебувають на службі в держави, зокрема судової влади. Досліджено справи ЕСПЛ Маgyar Helsinki Bizottsag v. Hungary, Thoma v. Luxemburg, CENTRE FOR DEMOCRACY AND THE RULE OF LAW v. Ukraine. Установлено роль організацій, щзо здійснюють важливу функиію «сторожового пса демокраmiï» (publicwatchdog). Наголошено, що «суди - гаранти справедливості, роль яких є основоположною в державі, де визнається й діє принцип верховенства права, - повинні користуватися довірою громадськості». Для цього необхідний контроль 3 боку недержавних громадських організацій $i$ ЗМІ як діяльності судової влади, так $i$ персоналу, який надає послуги з правосуддя. Досліджується діяльність судів через призму «довіра суспільства - відкритий суд - особа суддi». 
у дослідженні приділяеться увага статmі 11 Конвениії про захист прав людини $і$ основоположних свобод, розкривається ї̈ зміст за допомогою рішень ЕСПЛ.

також автор звертає увагу на позииію Ради Європи щодо судових органів і підкреслює тезу «правосуддя $є$ важливим компонентом демократичних суспільств». Це узгоджується відповідно до універсальних стандартів щодо правосуддя та прав людини.

Зроблено висновок, що опиія «publicwatchdog» $\epsilon$ чинною в демократичному суспільстві для вдосконалення державних інститутів, ЄСПЛ підтверджує изе в практиці. Суддя є фігурою сучасного суспільства, а отне, суспільний інтерес до такої фігури є виправданий для утвердження довіри до всієї судової влади й формування демократичної України. При изьому автор зазначає, що саме завдяки громадським організаціям, ЗМI, громадянам та адвокатам, які вивчають роботу судів (суддів), аналізують сучасний стан правосуддя, повідомляють про рівень «доступу до правосуддя» та загальну практику в судах за окремими категоріями справ, формується думка про судову владу.

Ключові слова: міжнародна судова установа, судова влада України, функціонування судової системи, демократія, «сторожовий пес демократії».

Bila-Kyseleva A. View of the European Human Rights Court about role the "publicwatchdog" for integration of justice in the society

The article analyzes the decisions of the European Court of Human Rights in terms of the activities of persons serving in the state, in particular, the judiciary. The cases of the European Court of Human Rights have been investigated: Magyar Helsinki Bizottsag v. Hungary, Thoma v. Luxemburg, CENTRE FOR DEMOCRACY AND
THE RULE OF LAW v. Ukraine. The role of organizations performing the important function of the watchdog of democracy (publicwatchdog) has been established. It is emphasized that "courts - guarantors of justice, whose role is fundamental in a state where the rule of law is recognized and enforced - should enjoy public trust". This requires scrutiny by nongovernmental organizations and the media of both the activities of the judiciary and staff providing justice services. The research focuses on the activities of the courts, through the prism of public trust - an open court the judge.

The study focuses on Article 11 of the Convention for the Protection of Human Rights and Fundamental Freedoms and reveals its content through the rulings of the European Court of Human Rights.

The author also draws attention to the position of the Council of Europe on the judiciary and emphasizes the thesis "justice is an important component of democratic societies". This is consistent with universal standards of justice and human rights.

It is concluded that the option "publicwatchdog" is a valid in democratic society for the improvement of state institutions, and the European Court of Human Rights confirms this in its practice. The judge is a figure of modern society, and therefore the public interest in such a figure is justified in order to establish confidence in the whole judiciary and to shape a democratic Ukraine.

At the same time, the author notes that the public interest in the judiciary exists due to public organizations, media, citizens and lawyers who study the work of courts (judges), analyze the current state of justice, report on the level of "access to justice".

Key words: international judiciary, judiciary of Ukraine, functioning of the judiciary, democracy, "publicwatchdog". 


\section{Література}

1. Рейган $P$. Жизнь по-американски. Москва: Новости, 1992. С. 723-724.

2. Конституиія України від 28.06.1996

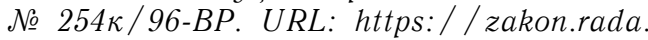
gov.ua/laws / show / $254 \%$ D0\%BA/96. $\%$ D0\% B2\% D1\% $80 \#$ n 4188 .

3. Висновок Консультативної ради європейських суддів до уваги Kомітету Міністрів Ради Європи № 7 (2005). URL: http: / / www.arbitr.gov.ua / files / pages / $\%$ D0\% $92 \%$ D0\% B $8 \%$ D $1 \% 81 \%$ D0\% BD $\%$ $D 0 \% B E \%$ DO $\%$ B2\% DO\% BE\% DO\% BA\% 20 $\%$ E2\% 84\% 96\% 207.pdf.

4. Де Сальвиа М. Прецеденты Европейского Суда по правам человека. Руководя щие принципы судебной практики, относящейся к Европейской конвениии о защите прав человека и основоположных свобод. Судебная практика с 1960 по 2002 г. Санкт-Петербург : Юридический центр Пресс, 2004. 1072 с.

5. Міжнародний пакт про економічні, соціальні $і$ культурні права від 16.12.1966. URL: https: / / zakon.rada.gov.ua/laws / card /995_042.

6. Конвениія про захист прав людини $i$ основоположних свобод від 04.11.1950. URL: https: / / zakon.rada.gov.ua/laws / show/995_004/ed19900101.
7. Piшення y cnpasi Sunday Times v. The United Kingdom (Application no. 6538/74). URL: https: / / hudoc.echr.coe.int/ rus \# $\{\% 22$ itemid\% 22: [\% 22001-57584\%22]\}.

8. Висновок Консультативної ради європейських суддів для Комітету міністрів Ради Європи про стандарти незалежності судових органів та незмінюваність суддів вid 01.01.2001 № 1 (2001). URL: https:// zakon.rada.gov.ua/laws / card/994_a52.

9. Piшення у справi Magyar Helsinki Bizottsag v. Hungary. URL: https:// strasbourgobservers.com / 2016/11/30/ magyar-helsinki-bizottsag-v-hungary-alimited-right-of-access-to-information-underarticle-10-echr/.

10. Piшенrя у cnpasi Thoma v. Luxemburg. URL: http:// uniset.ca/microstates2/lu_ thoma_hrcd.pdf.

11. Piшення у справі De Haesand Gijsels v. Belgium. URL: http://www.hrcr.org/ safrica / expression/dehaes_belgium.html.

12. Звіт Спеціального доповідача щодо незалежності суддів і юристів Комітету з прав людини ООН від 29 квітня 2019 року. URL: https: / / www.un.org / ru/.

13. Pішення у справі CENTRE FOR DEMOCRACY AND THE RULE OF LAW v. Ukraine. URL: https://hudoc.echr.coe.int / eng\#\{\%22itemid\% 22:[\% 22001-201896\%22]\}. 